\title{
Problem doboru jednostek odniesienia przestrzennego w integracji danych z drugiej połowy XIX i początku XX w. z terenów Galicji i Śląska Austriackiego*
}

\section{Krzysztof Ostafin}

https://orcid.org/0000-0002-4426-3211

Instytut Geografii i Gospodarki Przestrzennej, Uniwersytet Jagielloński

\section{Mateusz Troll}

https://orcid.org/0000-0002-7046-4869

Instytut Geografii i Gospodarki Przestrzennej, Uniwersytet Jagielloński

\section{Dominik Kaim}

https://orcid.org/0000-0001-8004-6890

Instytut Geografii i Gospodarki Przestrzennej, Uniwersytet Jagielloński

\section{Jakub Taczanowski}

https://orcid.org/0000-0001-9421-5982

Instytut Geografii i Gospodarki Przestrzennej, Uniwersytet Jagielloński

Zarys treści: Do poprawnego analizowania kartograficznych danych historycznych niezbędne są właściwe jednostki odniesienia przestrzennego. Zmiany granic administracyjnych mogą być powodem problemów $\mathrm{z}$ integracją danych pochodzących z map i zestawień tabelarycznych, zwłaszcza w przypadku powiatów. Odpowiednim poziomem organizacji tego rodzaju masowych danych może być gmina katastralna, która pozwala w znacznym stopniu uniezależnić się od późniejszych zmian administracyjnych i tworzy wiarygodną podstawę do agregacji danych na dowolnym wyższym szczeblu administracyjnym. W niniejszym artykule rozważono różne aspekty doboru jednostek przestrzennych dla danych z drugiej połowy XIX i początku XX w. z terenów Galicji i Śląska Austriackiego.

Słowa kluczowe: granice administracyjne, gmina katastralna, powiat, podział administracyjny, Galicja, Śląsk Austriacki
Abstract: To map and analyze spatial historical data, accurate territorial units are needed. Changes of administrative boundaries could cause a problem for linked maps to tabular socio-economic census data. A cadastral commune can be the appropriate spatial level for mass published census data. It allows to become independent from later changes of administrative units and it could be a good starting point to link similar data for higher level of administrative hierarchy. The article presents various aspects of the selection of administrative units for the mid-nineteenth century and the beginning of the twentieth century for Galicia and Austrian Silesia.

Keywords: administrative boundaries, cadastral commune, district, administrative division, Galicia, Austrian Silesia

\footnotetext{
* Artykuł prezentuje wybrane wyniki projektu „Opracowanie interaktywnej bazy danych Galicji i Śląska Austriackiego w latach 1857-1910" (nr laH 150324 83) finansowanego ze środków programu Ministra Nauki i Szkolnictwa Wyższego pod nazwą „Narodowy Program Rozwoju Humanistyki", realizowanego w latach 2015-2020.
} 


\section{Wprowadzenie}

Brak właściwych i szczegółowych jednostek odniesienia przestrzennego może być poważną barierą w analizowaniu i kartograficznej wizualizacji danych, ponieważ dla większości geografów mapa jest zarówno narzędziem badawczym, podstawą analiz przestrzennych, jak i formą prezentacji wyników badań ${ }^{1}$. W czasach technologii cyfrowych mapa przestała być dziełem statycznym, stając się dynamiczną bazą danych, która integruje geometrię obrazu z jego atrybutami, a także relacjami i zapytaniami obsługiwanymi przez systemy informacji geograficznej (GIS)2 . To właśnie dzięki zwiększeniu pojemności informacyjnej map oraz możliwościom dokonywania złożonych analiz i wizualizacji GIS wytyczył jedną z ważnych dróg powtórnego włączenia przestrzennych danych historycznych we współczesny obieg naukowy ${ }^{3}$. Obecnie wzrasta zapotrzebowanie na cyfryzację danych historycznych i udostępnianie ich $\mathrm{w}$ postaci przestrzennych baz danych ${ }^{4}$.

W przypadku powstających od połowy XIX w. danych historycznych dotyczących wielu obszarów Polski, Europy i świata możliwa jest organizacja w rozdzielczości porównywalnej ze współczesnymi wielkoskalowymi danymi kartograficznymi i bazami, które udostępniają takie urzędy, jak Bank Danych Lokalnych ${ }^{5}$, Główny Urząd Statystyczny czy Czeski Urząd Statystyczny ${ }^{6}$. Jeżeli jednak opracowania nie zawierają kartograficznej dokumentacji

\footnotetext{
${ }^{1}$ W. Żyszkowska, Analizy przestrzenne w systemach informacji geograficznej, „Polski Przegląd Kartograficzny”, 35 (2), 2003, s. 100-113.

2 M.-J. Kraak, F. Ormeling, Kartografia. Wizualizacja danych przestrzennych, Warszawa 1998.

${ }^{3}$ A.K. Knowles, Introducing historical GIS, w: Past time, past place. GIS for history, ed. A.K. Knowles, Redlands 2002, s. 11-20.

${ }^{4}$ B. Szady, Geografia historyczna w Polsce - rozwój i perspektywy, ,„Studia Geohistorica", 1, 2013, s. 19-38; tenże, Czasowo-przestrzenne bazy danych jako narzędzie w geografii historycznej, „Acta Universitatis Lodziensis. Folia Geographica Socio-Oeconomica", 14, 2013, s. 17-32.

5 „Bank Danych Lokalnych” (https://bdl.stat.gov.pl/BDL/start, dostęp: 6 kwietnia 2020).

6 „Český statistický úrad” (https://www.czso.cz/, dostęp: 6 kwietnia 2020).
}

przebiegu granic administracyjnych ${ }^{7}$, to odbiorca może mieć trudności z jednoznaczną identyfikacją obszarów, do których odnoszą się dane społeczno-gospodarcze, ponieważ w wielu przypadkach sama nazwa jednostki administracyjnej okazuje się niewystarczająca.

Na trudności w rekonstrukcji jednostek odniesienia przestrzennego (np. okręgów sanitarnych, parafii różnych obrządków czy powiatów) oraz odtworzeniu zmian granic administracyjnych zwracano uwagę w wielu publikacjach ${ }^{8}$. Skala trudności wzrasta tym bardziej, im odleglejsze są badane czasy?.

W XIX w. kartografia i metody zbierania danych społeczno-ekonomicznych zostały znacząco udoskonalone w wielu krajach, np. w Cesarstwie Austrii (od 1867 r. Austro-Węgrzech). Mapy topograficzne zaczęły bazować na solidnych podstawach matematycznych i ujednoliconych instrukcjach. Podczas kartowania obiektów w terenie wykorzystywano udoskonalone przyrządy pomiarowe i gęstą sieć triangulacyjną związaną z katastrem ${ }^{10}$. Po zorganizowanym w 1853 r. Międzynarodowym Kongresie Statystycznym w Brukseli, gdzie przedstawione zostały zasady normalizacji i unowocześnienia spisów ludnościowych (m.in. zbierania danych imiennych i opartych na

\footnotetext{
Przykładowo w opracowaniu Grzegorza Chromika, Geschichte des deutsch-slawischen Sprachkontaktes im Teschener Schlesien brakuje mapy wzbogacającej przekaz. Podobnie jest w znakomitej serii Informatorów statystycznych do dziejów gospodarczych Galicji, choć autorzy i redaktorzy thumaczą te trudności zmianami w liczbie (powierzchni) powiatów. G. Chromik, Geschichte des deutsch-slawischen Sprachkontaktes im Teschener Schlesien, Regensburg 2018.

${ }^{8}$ A. Burzyński, Górnictwo, hutnictwo i przemyst rafineryjny (struktura zatrudnienia na tle wartości i wielkości produkcji), w: Informator statystyczny do dziejów przemysłu w Galicji, red. H. Madurowicz-Urbańska, Kraków 1982, s. 227; M. Soja, Cykle rozwoju ludności Karpat Polskich w XIX i XX wieku, Kraków 2008.

${ }^{9}$ K. Chłapowski, Granice i podziały administracyjne Królestwa Polskiego iRzeczypospolitej Obojga Narodów w XV-XVIII wieku, ,Studia Geohistorica”, 7, 2019, s. 163-189; H. Rutkowski, $A$ few comments on the historical borders in Poland, „Studia Geohistorica”, 6, 2018, s. 5-135.

${ }^{10}$ A. Konias, Kartografia topograficzna Śląska Cieszyńskiego i zaboru austriackiego od II połowy XVIII wieku do początku XX wieku, Katowice 2000; F.P. Faluszczak, Kartografia Galicji Wschodniej w latach 1772-1914, Rzeszów 2011; Galicja na józefińskiej mapie topograficznej. 1779-1783, t. 1, red. W. Bukowski, B. Dybaś, Z. Noga, Kraków 2012.
} 


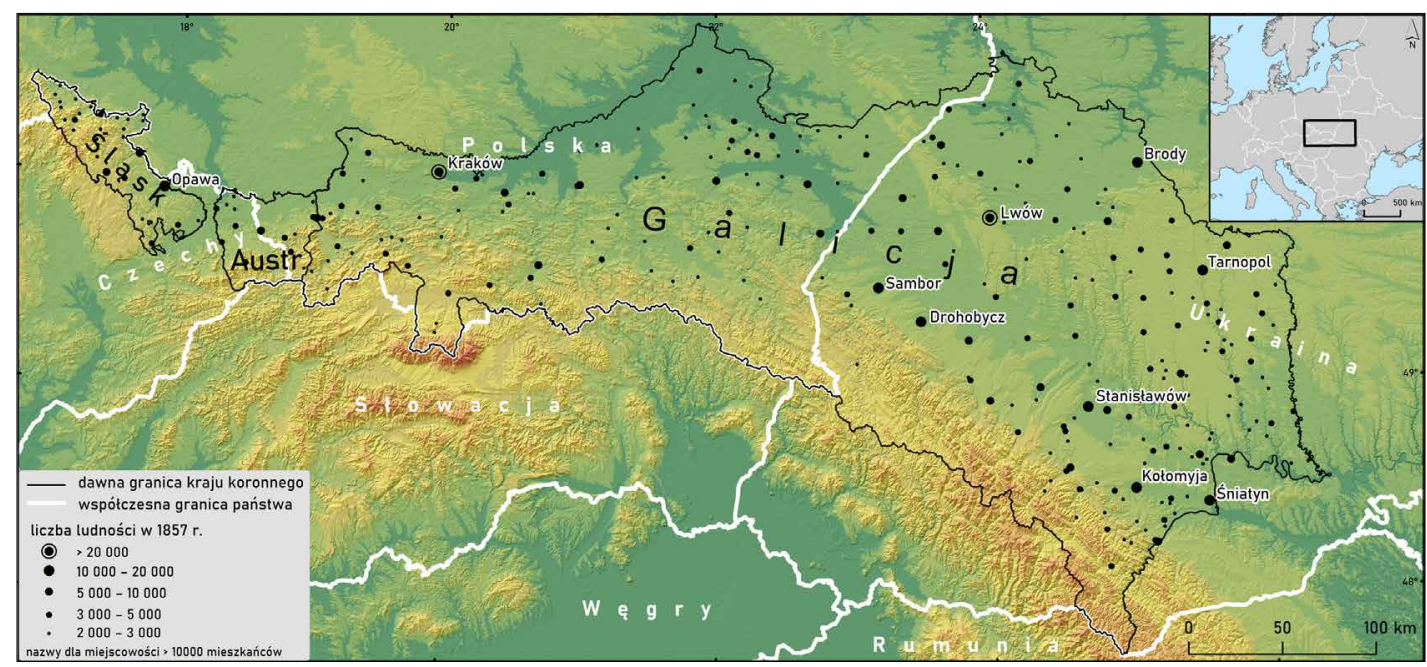

Ryc. 1. Położenie obszaru badań

Żródto: oprac. własne na podkładzie danych wysokościowych: „EU-DEM v.1.1”, ,Copernicus” (https://land.copernicus.eu/imagery-in-situ/eu-dem/eu-dem-v1.1, dostęp: 27 kwietnia 2020) oraz danych o liczbie ludności dla miejscowości w 1857 r.: „Statistische Übersichten über die Bevölkerung und den Viehstand von Österreich nach der zählung vom 31. October 1857", Wien 1859

ludności rzeczywistej oraz dziesięcioletnich powtórzeniach $\left.{ }^{11}\right)$, spisy przeprowadzono także w Austrii i Austro-Węgrzech, w latach $1857,1869,1880,1890,1900,1910$. Od 1869 r. uznaje się je za nowoczesne ${ }^{12}$.

Niniejszy artykuł ma na celu przedstawienie problemów w doborze historycznych jednostek odniesienia przestrzennego dla publikowanych danych społeczno-gospodarczych pochodzących ze wspomnianych spisów.

\section{Obszar badań}

Obszarem badań są dawne terytoria Galicji i Śląska Austriackiego - krajów koronnych (niem. Kronland) (ryc. 1). Galicja, a ściślej Królestwo Galicji i Lodomerii wraz z Wielkim Księstwem Krakowskim oraz Księstwem Oświęcimia i Zatoru, obejmowała tereny włączone do Cesarstwa Austrii w wyniku pierwszego rozbioru Polski w 1772 r. oraz obszar Rzeczypospolitej Krakowskiej wcielonej w 1846,

${ }^{11}$ C. Domański, Rola polskich statystyków w Międzynarodowym Instytucie Statystycznym, ,Przegląd Statystyczny”, 62 (4), 2015, s. 457-469.

${ }_{12}$ A. Rzepkowski, Spisy ludności na ziemiach polskich w latach 1789-1913, „Przegląd Nauk Historycznych”, 2 (8), 2005, s. 101-123. z późniejszym wyłączeniem Bukowiny (od 1849 r. istniało Księstwo Bukowiny). Drugi obszar - Śląsk Austriacki, złożony ze Śląska Cieszyńskiego i Śląska Opawskiego - dostał się we władanie Habsburgów na skutek wygaśnięcia dynastii Piastów na Śląsku Cieszyńskim w 1653 r., a Śląsk Opawski - w wyniku uwarunkowań gospodarczych księstw opawskiego, karniowskiego i nyskiego. Granice Śląska Austriackiego ustalono w wyniku wojen austriacko-pruskich w połowie XVIII w. Były to kraje koronne mocno zróżnicowane pod względem powierzchni i liczby ludności. W 1857 r. Galicja liczyła $78490 \mathrm{~km}^{2}$ i 4597470 mieszkańców,

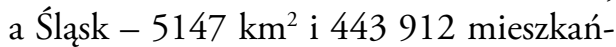
ców ${ }^{13}$. Do końca 1910 r. liczba ludności Galicji zwiększyła się do $8025421^{14}$, a Śląska Austriackiego - do $756949^{15}$.

\footnotetext{
${ }^{13}$ Zbiorcze zestawienie powierzchni i statystyk demograficznych wszystkich krajów monarchii na tle ich granic znajduje się na dziewiętnastym arkuszu mapy: J. Sched, General-Karte des Oesterreichischen Kaiserstaates mit einem grossen Theile der angränzenden Länder, skala: 1:576 000, 1856.

${ }^{14}$ Allgemeines Verzeichnis der Ortsgemeinden und Ortschaften Österreichs nach den Ergebnissen der Volkszählungvom 31. Dezember 1910, Wien 1915 ${ }^{15}$ Spezialortsrepertorium der Österreichischen Länder. Bearbeitet auf grund der ergebnisse der Volkszählung vom 31. Dezember 1910,
} 
Współcześnie 59,5 proc. obszaru dawnej Galicji należy do Ukrainy, a 40,5 proc. do Polski; 80,4 proc. powierzchni Śląska Austriackiego należy z kolei do Czech, a 19,6 proc. - do Polski. W sumie w granicach Rzeczypospolitej znajduje się dziś 39,2 proc. powierzchni tych dwóch dawnych krajów koronnych.

\section{Podział terytorialny Galicji i Śląska Austriackiego od połowy XIX w.}

Organizacja podziału administracyjnego Galicji i Śląska Austriackiego w badanym okresie poruszana była w wielu pracach z XIX w. ${ }^{16}$ i opracowaniach współczesnych ${ }^{17}$. W uproszczeniu można przyjąć, że najniższymi w hierarchii jednostkami przestrzennymi, do których odnoszą się różnorodne źródła masowe, w tym spisy, były dominia, gminy katastralne, gminy administracyjne (polityczne) i obszary dworskie. Gminy katastralne były jednostkami związanymi z organizacją i utrzymywaniem katastru gruntowego, natomiast dominia, a następnie gminy administracyjne i obszary dworskie - obszarami administracji lokalnej i jednostkami samorządowymi.

Przed powołaniem gmin administracyjnych jednostką administracyjno-majątkową najniższego szczebla było w Galicji i na

Herausgegeben von der K.K. Statistischen Zentralkommission XI. Schlesien, Wien 1917.

${ }^{16}$ Organizacji i krytyce podziału administracyjnego Galicji poświęcone są m.in. następujące opracowania: Projekt podziału administracyinego Królestwa Galicyi, Lodomeryi i W. Ks. Krakowskiego na 74 powiaty, Lwów 1866; F. Kasparek, Uwagi knytyczne o galicyjskiej organizacyi gminnej i wnioski reformy, Kraków 1880; T. Pilat, Podziat tentoryalny Galicyi według stanu z d. 1. stycznia 1883 r. tudzież obszar, ludność igęstość zaludnienia powiatów, „Wiadomości Statystyczne o Stosunkach Krajowych”, 8 (1) 1883, s. 1-45.

17 Podstawy prawne i kontekst polityczny reform administracyjnych w Galicji przedstawili Andrzej Dziadzio i Mateusz Mataniak: A. Dziadzio, M. Mataniak, Namiestnictwo galicyjskie (1854-1914). Organizacja izadania, ,Krakowskie Studia z Historii Państwa i Prawa", 11 (1), 2018, s. 137-167. Zarys przemian administracyjnych na Śląsku Austriackim zaprezentowali m.in. Dan Gawrecki, Krzystof Nowak oraz Danuta Kocurek i Wiesława Korzeniowska: D. Gawrecki, Granice i zmiany przynależności Śląska Cieszyńskiego do 1918 roku, w: Śląsk Cieszyński. Granice - przynależność - tożsamość, red. J. Spyra. Cieszyn 2008, s. 15-24; K. Nowak, Przemiany prawno-administracyine, społeczno-zawodowe inarodowościowe, w: Śląsk Cieszyński od Wiosny Ludów do I wojny światowej (1848-1918), red. I. Panic, Cieszyn 2013, s. 9-20; D. Kocurek, W. Korzeniowska, Śląsk Cieszyński w latach 1741-1918 w aspekcie czynników integrujących i dezintegrujących region. Studium monograficzne, Kraków 2013.
Śląsku Austriackim dominium (zwierzchność gruntowa). Dominia obejmowały całe miejscowości (jedną lub więcej) albo tylko ich części ${ }^{18}$. W latach 1848-1849 w Galicji istniało 2558 dominiów, w tym 2499 prywatnych $^{19}$, a w 1839 r. na Śląsku Austriackim - 124 dominia, w tym 56 na Śląsku Cieszyńskim. W Galicji jednostki te zniosła ustawa z 12 sierpnia 1866 r., zastępując je gminami administracyjnymi i obszarami dworskimi (niem. Gutsgebiete). Te drugie obejmowały grunty dawnej własności dominialnej, których właściciele nie przystąpili do organizowanych związków gminnych. W nielicznych przypadkach, gdy do tego dochodziło, dawne grunty dominialne wchodziły w skład gminy administracyjnej (najbardziej znanym przykładem są tu dobra arcyksięcia Albrechta Fryderyka Habsburga ${ }^{20}$ ). Ostatecznie obszary dworskie zostały zniesione dopiero w 1919 r., mocą ustawy o połączeniu obszarów dworskich z gminami ${ }^{21}$. Na Śląsku Austriackim dominia zlikwidowano wcześniej, w 1848 r. Nie wprowadzono tam obszarów dworskich, a dawne majątki dominialne, np. dobra istniejącej od $1654^{22}$ do 1918 r. Komory Cieszyńskiej (niem. Teschner lub Teschener Kammer) nadal funkcjonowały w ramach gmin katastralnych. Ich przynależność do dawnych dominiów podawana była jeszcze w wykazie gmin z $1850 \mathrm{r}^{23}$, ale w późniejszych wydawnictwach statystycznych nie wyodrębniano już dawnych dominiów, wskazując jedynie liczbę wielkich posiadłości ziemskich (niem. Großgrundbesitzungen).

\footnotetext{
${ }^{18}$ K. Ślusarek, W przededniu autonomii. Własność ziemska i ziemiaństwo zachodniej Galicji w połowie XIX wieku, Warszawa 2013.

19 S. Kieniewicz, Sprawa wtościańska w Galicji w 1848, „Przegląd Historyczny”, 38, 1948, s. 61-128.

${ }_{20}$ T. Pilat, Własność tabularna w Galicyi, „Wiadomości Statystyczne o Stosunkach Krajowych", 12, 1891.

${ }^{21}$ Ustawa z dnia 26 lipca 1919 r. o połączeniu obszarów dworskich z gminami, obowiązująca na terytorium b. Galicji, Dz.U. 1919, nr 67, poz. 404.

22 J. Chlebowczyk, Gospodarka Komory Cieszyńskiej na przełomie XVII-XVIII oraz w pierwszej połowie XVIII w., Wrocław-Warszawa-Kraków 1966.

${ }^{23}$ Alphabetiäch geordnetes Orts = Verzeichnitz der Kronländer Mähren und Schlelien nach der k. k. politilchen Adminittrations und Gerichtseintheilung, Olmüz-Neutitchein 1850.
} 
Wskutek powołania w Galicji gmin administracyjnych i obszarów dworskich jednej gminie katastralnej odpowiadały najczęściej jedna gmina administracyjna i jeden obszar dworski, jak w przypadku Zakopanego (ryc. 2a). Gdy właściciel dawnego dominium przystępował do związku gminnego, obszar gminy katastralnej mógł się pokrywać z obszarem gminy administracyjnej, czego przykładem są Jawiszowice koło Oświęcimia (ryc. 2b).

Istniały również bardziej złożone relacje. Grunty kilku różnych gmin katastralnych mogły zostać włączone do jednej gminy administracyjnej, poza którą pozostawało kilka obszarów dworskich (przykład gminy administracyjnej Wrzawy - ryc. 2c). W takiej sytuacji odniesieniem przestrzennym danych spisowych było zgrupowanie kilku gmin katastralnych. W odwrotnej na gruntach jednej gminy katastralnej powstawało kilka gmin administracyjnych i obszarów dworskich (przykład gminy katastralnej Złoczów - ryc. 2d). Odniesieniem przestrzennym danych spisowych była wówczas jedna gmina katastralna. Zdarzało się też wreszcie, że dwie części obszaru dworskiego należały do różnych gmin katastralnych (ryc. 2e).

$\mathrm{Na}$ Śląsku Austriackim jedna gmina katastralna obejmowała najczęściej jedną gminę polityczną. W 1900 r. wyjątkiem była gmina katastralna Cierlicko na Śląsku Cieszyńskim (niem. Tierlitzko, czes. Těrlicko) składająca się z gmin Cierlicko Dolne (niem. Niedertierlitzko, czes. Dolní Těrlicko) i Cierlicko Górne (niem. Obertierlitzko, czes. Horní Těrlicko). Dostępność szkiców indykacyjnych ${ }^{24} \mathrm{w}$ skali 1:1440 pozwala na dokonywanie prób wydzielania części gmin administracyjnych (ryc. 2f), a tym samym zwiększanie rozdzielczości przestrzennej jednostek odniesienia. Podczas takiej rekonstrukcji granic mogą jednak występować przypadki, gdy

${ }^{24}$ Szkice te udostępnia online Zemský archiv v Opavě (https://archivnimapy. cuzk.cz/uazk/pohledy/archiv.html, dostęp: 27 kwietnia 2020). część miejscowości należała do różnych gmin administracyjnych i katastralnych. Przykładem jest Altkaltenstein (czes. Staré Podhradí), który dzielił się na części $1 \mathrm{~A}$ i $2 \mathrm{~A}$, należące odpowiednio do gmin administracyjnych i katastralnych Schwarzwasser (czes. Černá Voda) oraz Setzdorf (czes. Zighartice, od 1949 r. Vápenná) ${ }^{25}$.

Okres od końca lat czterdziestych do schyłku sześćdziesiątych XIX w. był w Galicji i na Śląsku Austriackim czasem reform administracyjnej organizacji powiatów. Gminy utworzyły powiaty sądowe, które z kolei weszły w skład powiatów politycznych (starostw). Podział na 109 powiatów wprowadzono w Galicji w latach 1854 1855, choć istniał wtedy jeszcze podział na cyrkuły (obwody). Ówczesne powiaty były jednocześnie okręgami sądownictwa i administracji politycznej. Zgodnie z rozporządzeniem ministerstwa stanu z 23 stycznia 1867 r. Galicję podzielono na 74 nowe powiaty polityczne oraz równe im rangą miasta Kraków i Lwów, mające własne statuty. Pod koniec grudnia 1867 r. weszła w życie zasada rozdziału władzy administracyjnej od sądowniczej - usunięto pozostałości sądowniczej jurysdykcji starostw powiatowych i ukształtowały się nowe powiaty sądowe ${ }^{26}$. Podobnie było na Śląsku Austriackim, gdzie powstały powiaty polityczne (7 w 1869 i $9 \mathrm{w} 1910 \mathrm{r}$.) oraz sądowe (23 w 1869 i 25 w 1910 r.) wraz z miastami z własnym statutem - najpierw Opawą (niem. Troppau, czes. Opava), a później Frydkiem (niem. Friedek, czes. Frýdek, ob. Frýdek-Místek) i Bielskiem (niem. Bielitz, ob. Bielsko-Biała). Najmłodszym powiatem sądowym, utworzonym po 1900 r., była Polska Ostrawa (niem. Polnisch Ostrau, czes. Polská Ostrava), nazywana też Śląską Ostrawą (czes. Slezská Ostrava).

\footnotetext{
${ }^{25} \mathrm{~K}$. Ostafin et al., Historical dataset of administrative units with social-economic attributes for Austrian Silesia 1837-1910, „Scientific Data”, 7 (208), 2020, s 1-14. Dane dostępne na stronie: „Harvard Dataverse” (https:// dataverse.harvard.edu/dataset.xhtml?persistentld=doi:10.7910/DVN/ KTYPAF, dostęp: 10 lipca 2020).

${ }^{26}$ A. Dziadzio, M. Mataniak, Namiestnictwo.
} 


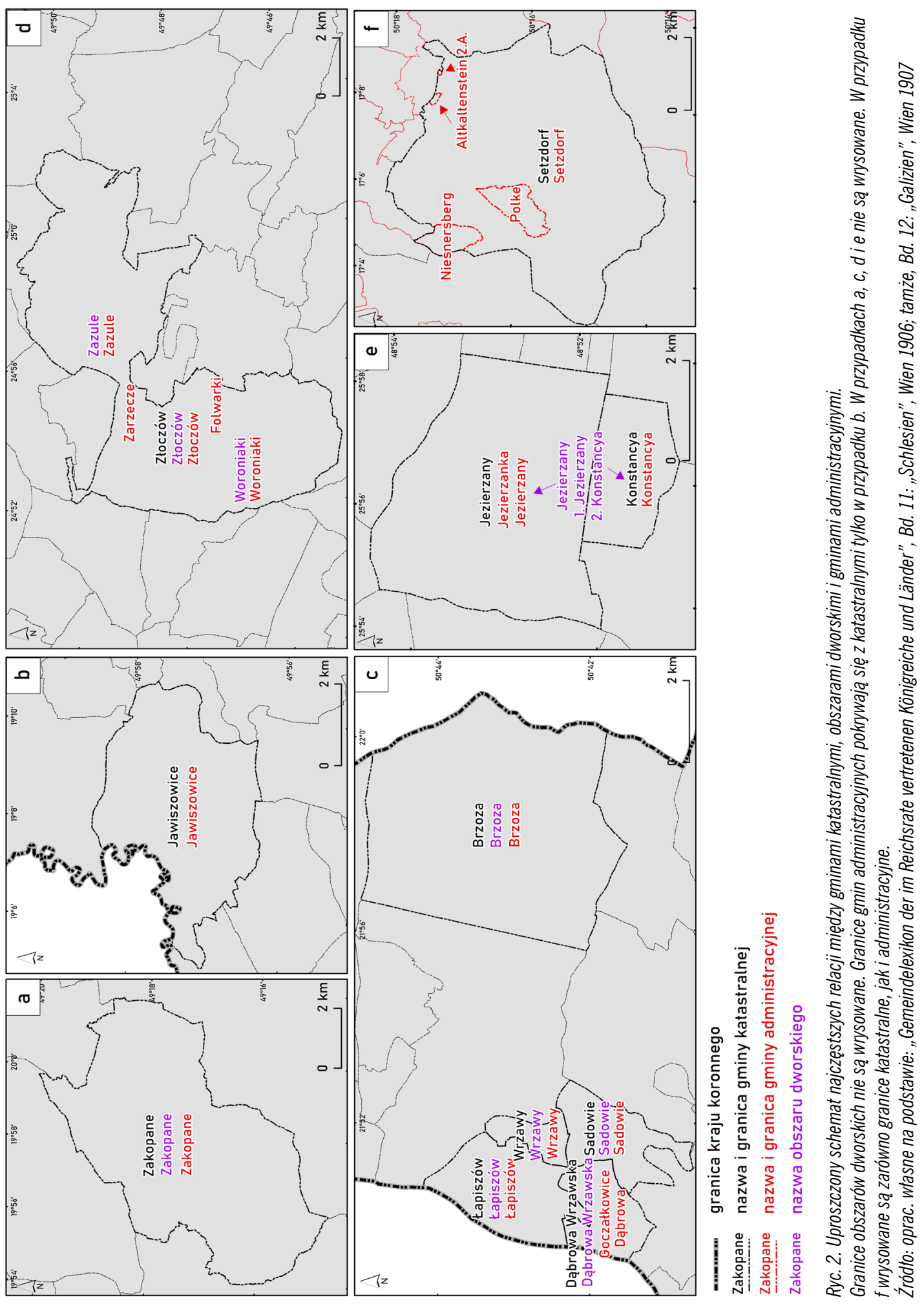




\section{Dobór jednostek odniesienia przestrzennego}

Przy opracowywaniu dużego i podzielonego współczesnymi granicami państwowymi obszaru pojawia się dylemat, jaki poziom odniesienia przestrzennego uznać za najbardziej efektywny. Nawiązując do wyżej przedstawionej organizacji podziału terytorialnego, można rozważać kilka możliwości.

\subsection{Poziom bardziej szczegółowy niż gmina katastralna}

Możliwość wyboru najbardziej szczegółowych poziomów odniesienia przestrzennego dają operaty stałego katastru gruntowego opracowane na podstawie szczegółowego zdjęcia terenowego, które wykonano w latach 1824-1830 i 18441854 w przypadku Galicji oraz w latach 1824-1830 i 1833-1836 w przypadku Śląska Austriackiego i Moraw. Skala podstawowa przyjmuje tu wielkość $1: 2880$ (w górach 1:5760, a w miastach 1:1440) ${ }^{27}$. Powstałe wówczas plany katastralne oraz operaty opisowe (m.in. protokoły parcelowe, alfabetyczne spisy posiadaczy gruntów i budynków), a także akta będące wynikiem późniejszych rewizji katastru gruntowego umożliwiają operowanie poziomem odniesienia przestrzennego $\mathrm{w}$ postaci parceli gruntowej i budowlanej lub na przykład nieruchomości gruntowej ${ }^{28}$.

W drugiej połowie XIX w. spisy ludnościowe zaczęły być powszechne, a dane statystyczne zbierano na szczegółowych formularzach dla każdego mieszkańca monarchiii ${ }^{29}$. Lidia Zyblikiewicz, opra-

${ }^{27}$ Instruktion zur Ausführung der Vermessungen mit Anwendung des Mesztiches behufs Herstellung neuer Pläne für die Zwecke des Grundsteuerkatasters, Vienna 1907.

${ }^{28}$ J. Stoksikówna, Galicyjski kataster gruntowy, jego geneza, dzieje i spuścizna aktowa, „Archeion”, 63, 1975, s. 165-187; J. Wolski, Austriacki kataster podatku gruntowego na ziemiach polskich oraz jego wykorzystanie w pracach urządzeniowych i badaniach naukowych, „Polski Przegląd Kartograficzny", 32 (3), 2000, s. 199-212.

${ }^{29}$ A Burzyński, Z rozważań nad oceną austriackich powszechnych spisów ludności z lat 1869-1910, „Przesztość Demograficzna Polski”, 15, 1984, s. 59-69; P. Teibenbacher, D. Kramer, W. Göderle, An inventory of Austrian census materials, 1857-1910. Final report, Rostock 2012 (Mosaic Working Paper, WP2012-007). cowując zagadnienie struktury demograficznej, zawodowej i społecznej ludności Krakowa w drugiej połowie XIX w., sięgała m.in. do zachowanych oryginalnych kart powszechnych spisów ludności, co pozwoliło uchwycić złożone zależności oraz odpowiednio grupować, klasyfikować i analizować dane ${ }^{30}$. Krzysztof Ślusarek wykorzystał natomiast operaty uwłaszczeniowe, by przedstawić liczebność, rozmieszczenie i strukturę społeczno-majątkową właścicieli dóbr ziemskich w zachodniej Galicji z połowy XIX w. ${ }^{31}$ Powyższe teksty są świetnymi przykładami opracowania spisów, które mogą zostać naniesione na szczegółowe mapy w dalszych etapach pracy nad tymi zagadnieniami. Konrad Wnęk z użyciem planów katastralnych badał własność nieruchomości w Krakowie w połowie XIX w. $\left(8,3 \mathrm{~km}^{2}\right)^{32}$, Jacek Wolski $^{33}$, Andrzej Affek ${ }^{34}$ oraz Michał Sobala, Oimahmad Rahmonov i Urszula Myga-Piątek ${ }^{35}$ opracowywali użytkowanie ziemi w gminach katastralnych odpowiednio w Bieszczadach Wysokich $\left(61,7 \mathrm{~km}^{2}\right)$, dorzeczu górnego Wiaru $\left(233 \mathrm{~km}^{2}\right)$ oraz Beskidzie Śląskim i Beskidzie Żywieckim (ok. $100 \mathrm{~km}^{2}$ ). Opracowanie większych obszarów wymaga jednak długoletnich przedsięwzięć skupionych wylącznie na danych katastralnych. W latach 2008-2011 w ramach projektu „Der Franziszeische Kataster in Österreichisch Schlesien (18241871). Edition, Digitalisierung, Analyse"36

\footnotetext{
${ }^{30}$ L.A. Zyblikiewicz, Ludność Krakowa w drugiej połowie XIX wieku. Struktura demograficzna, zawodowa i spoteczna, Kraków 2014.

${ }^{31} \mathrm{~K}$. Ślusarek, W przededniu.

${ }^{32}$ K. Wnęk, Wtasność nieruchomości w Krakowie w połowie XIX w., Kraków 2011.

33 J. Wolski, Przekształcenia krajobrazu wiejskiego Bieszczadów Wysokich w ciagu ostatnich 150 lat, Warszawa 2007 (Prace Geograficzne IGiPZ PAN, 214).

${ }^{34}$ A. Affek, Dynamika krajobrazu. Uwarunkowania i prawidłowości na przykładzie dorzecza Wiaru w Karpatach (XVIII-XXI wiek), Warszawa 2016 (Prace Geograficzne IGiPZ PAN, 251).

${ }_{35}$ M. Sobala, O. Rahmonov, U. Myga-Piątek, Historical and contemporary forest ecosystem changes in the Beskid Mountains (southern Poland) between 1848 and 2014, „FFrest - Biogeosciences and Forestry”, 10, 2017, s. 939-947.

36 „Der Franziszeische Kataster” (http://www.franziszeischerkataster.at, dostęp: 27 kwietnia 2020).
} 


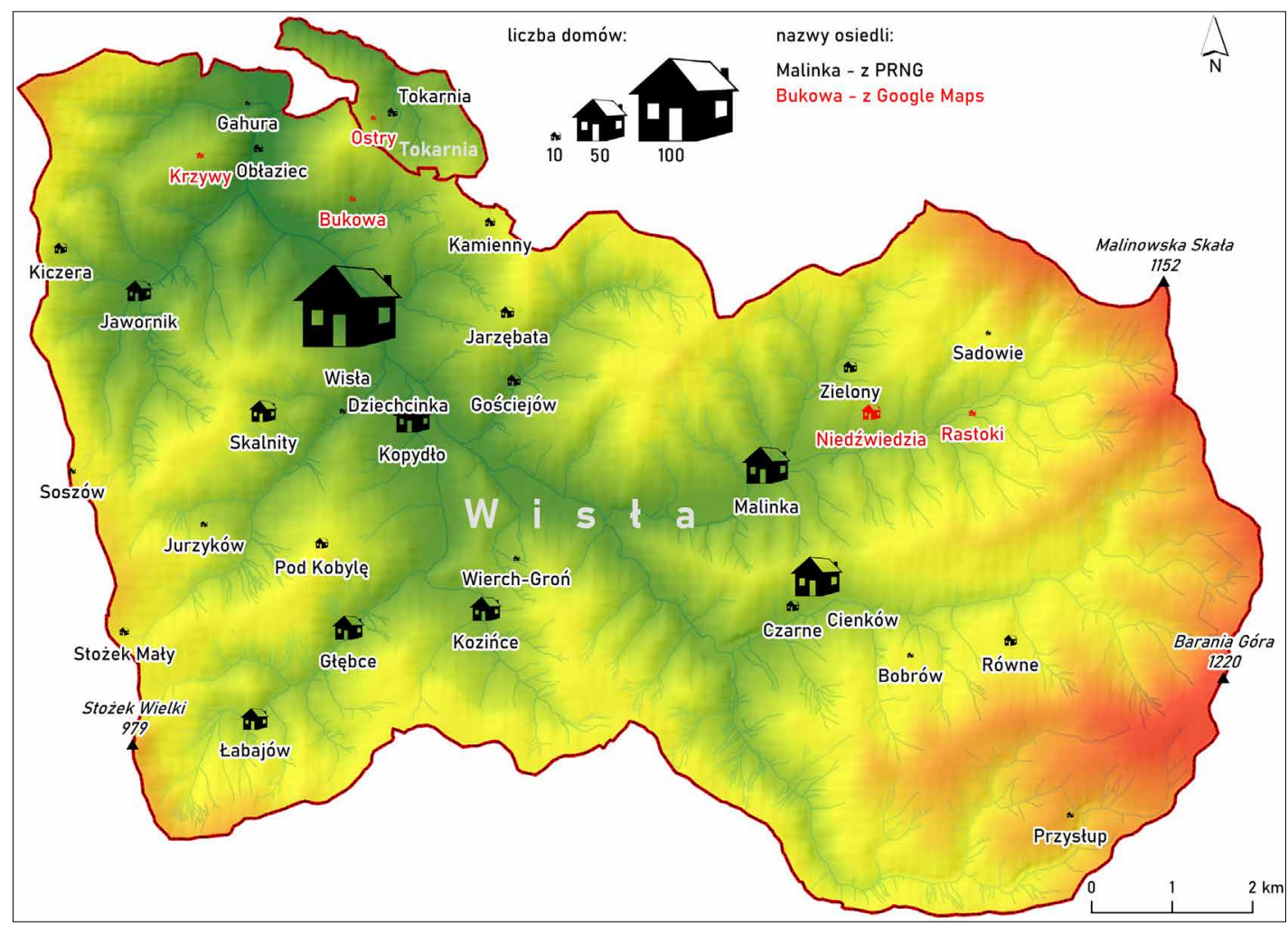

Ryc. 3. Przykład integracji danych społeczno-gospodarczych na poziomie osiedli w powiązaniu z Państwowym Rejestrem Nazw Geograficznych i Google Maps dla Wisty w 1890 r.

Żródło: oprac. własne na podkładzie danych wysokościowych: „EU-DEM v.1.1", „Copernicus” (https://land.copernicus.eu/imagery-in-situ/eu-dem/eu-dem-v1.1, dostęp: 27 kwietnia 2020)

opracowano dane odnośnie do Bukowiny $\left(10442 \mathrm{~km}^{2}\right)$ i Karyntii (ok. 10327 $\left.\mathrm{km}^{2}\right)^{37}$. Jak dotąd nie zostały one jednak udostępnione w postaci edytowalnej ${ }^{38}$. W 2018 r. rozpoczęto opracowanie katastru Śląska Austriackiego, które ma zostać zakończone w 2021 r. Podobna praca nad katastrem Galicji zajmie zapewne ok. 8-9 lat, a dodatkową barierą może być rozproszenie i niekompletność zbiorów ${ }^{39}$.

\footnotetext{
${ }^{37}$ Gemeindelexikon der im Reichsrate vertretenen Königreiche und Länder, Bd. 5: Kärnten, Wien 1905; tamże, Bd. 13: Bukowina, Wien 1907.

${ }^{38}$ Powstała natomiast publikacja z wynikami projektu dla Bukowiny: H. Rumpler, K. Scharr, C. Ungureanu, Der Franziszeische Kataster im Kronland Bukowina Czernowitzer Kreis (1817-1865). Statistik und Katastralmappen, Wien-Köln-Weimar 2015.

${ }^{39}$ J. Stoksik, Galicyjski kataster gruntowy - jego gromadzenie iopracowywanie w Archiwum Państwowym w Krakowie, ,Krakowski Rocznik Archiwalny”, 1, 1995, s. 46-57; D. Nowak, Austriackie katastry gruntowe w zasobach
}

Innym poziomem odniesienia $\mathrm{w}$ obrębie gmin katastralnych mogą być ich części, przysiółki i osiedla. Na podstawie publikowanych, dostępnych online materiałów dotyczących Galicji i Śląska Austriackiego można dokonać zintegrowania spisowych danych społeczno-ekonomicznych z osiedlami w wybranych przekrojach czasowych. Wydzielanie tych jednostek nie jest jednak spójne w publikacjach z różnych przekrojów czasowych. Na przykład w Orts-Repertorium ${ }^{40}$ z 1890 r. dane o liczbie ludności, domów, wyznaniach i językach w gminie Wisła obejmują 33 osiedla,

Centralnego Historycznego Archiwum Państwowego Ukrainy we Lwowie, „Krakowskie Pismo Kresowe”, 11, 2019, s. 37-53.

${ }^{40}$ Spezial Orts-Repertorium von Schlesien Neubearbeitung auf grund der ergebnisse der Volkszählung vom 31. Dezember 1890, Wien 1894. 
które można w większości dowiązać punktowo do współczesnego Państwowego Rejestru Nazw Geograficznych (PRNG), a w przypadku brakujących nazw - ustalić je np. z serwisu "Google Maps” (ryc. 3). W zestawieniu z $1900 \mathrm{r}^{41}$ dla tej samej gminy wymienione są tylko dwie części Wisła i Tokarnia.

\subsection{Poziom gminy katastralnej}

Następnym poziomem przestrzennej agregacji danych mogą być granice gmin katastralnych pozyskane $\mathrm{w}$ mniejszej skali z kompletnego i spójnego podkładu kartograficznego. Warunek ten spełnia tzw. drugie wojskowe zdjęcie topograficzne w skali 1:28 800, opracowane w wyniku generalizacji katastru ${ }^{42}$. Wyrysowano na nim granice gmin katastralnych o dokładniejszej i bardziej szczegółowej geometrii niż na mapie Kummerera von Kummersberga w skali ok. 1:115 200 ${ }^{43}$. Obszar Śląska Austriackiego obejmują 42 arkusze sporządzone w latach 1837-1841, a Galicję - 413 arkuszy z lat 1861-1864 (ryc. 4). Zostały one zakupione w Austriackim Archiwum Państwowym (niem. Österreichisches Staatsarchiv) jako skany w formacie tiff o rozdzielczości 300 dpi. Każdy arkusz drugiego zdjęcia topograficznego poddany został korekcji geometrycznej, połączonej $\mathrm{z}$ transformacją do odwzorowania UTM we właściwej strefie (w przypadku Czech i Ukrainy) lub odwzorowania GaussaKrügera w układzie współrzędnych PL1992 (w przypadku Polski). Do korekcji geometrycznej drugiego zdjęcia wykorzystywano głównie wysokorozdzielcze obrazy satelitarne World Imagery ${ }^{44}$ oraz Digital Globe, a także mapy topograficzne (polskie w skali 1:25 $000 \mathrm{z}$ końca lat

\footnotetext{
${ }^{41}$ Gemeindelexikon, Bd. 11: Schlesien, Wien 1906.

${ }^{42}$ A. Konias, Kartografia.

${ }^{43}$ C. Kummerer Ritter von Kummersberg, Administrativ-Karte von den Königreichen Galizien und Lodomerien mit dem Grossherzogthume Krakau und den Herzogthümern Auschwitz, Zator und Bukowina in 60 Blättern, Wien 1855. Mapa ta ma także co najmniej jeszcze jedną, spójną edycję z $1880 \mathrm{r}$.

${ }^{44}$ World Imagery, ,Arc GIS" (https://www.arcgis. com/home/item.html?id=1 Odf2279f9684e4a9f6a7f08febac2a9, dostęp: 6 kwietnia 2020).
}

siedemdziesiątych i początku osiemdziesiątych XX w. w przypadku karpackiej części Galicji znajdującej się obecnie w granicach Polski ${ }^{45}$ oraz rosyjskie mapy wojskowe w skali 1:50 $000 \mathrm{z}$ lat siedemdziesiątych i osiemdziesiątych XX w. w przypadku części Galicji należącej do Ukrainy). W przypadku arkuszy Śląska Austriackiego zastosowano metodę transformacji liniowej (afinicznej), a w galicyjskich, na których możliwe było wyznaczenie od 20 do 40 równomiernie rozmieszczonych punktów kontrolnych - metodę wielomianową drugiego stopnia. Jedynie w przypadku arkuszy skrajnych, wypełnionych treścią w niewielkiej części, zastosowana została metoda transformacji liniowej. Średnie błędy transformacji (RMS) wynosity na ogół od kilkunastu do dwudziestu kilku metrów, sporadycznie sięgając trzydziestu kilku metrów. Błędy te są o połowę mniejsze niż w przypadku drugiego zdjęcia topograficznego udostępnionego na portalu „Mapire”46.

Granice gmin katastralnych zrekonstruowano metodą manualnej wektoryzacji poprzez nałożenie wektorowych granic obrębów ewidencyjnych pozyskanych z Państwowego Rejestru Granic ${ }^{47}$ i czeskiego geoportalu ĆÚZK ${ }^{48}$. W przypadku obszaru przynależnego do współczesnej Ukrainy wektoryzowano od podstaw, gdyż nie dysponowano tutaj modelem wektorowym. W ten sposób zrekonstruowane zostało 585 gmin katastralnych i ponad 700 innych jednostek Śląska Austriackiego (w tym gmin administracyjnych i ich części). Dla porównania Gemeindelexikon z 1900 r. podaje 585 gmin katastralnych i 498 administracyjnych. W przypadku Galicji zwektoryzowano zaś 5965 jednostek, głównie gmin katastralnych, a w niektórych miejscach także gmin

\footnotetext{
${ }^{45}$ W projekcie FORECOM: „FORECOM” (http://www.gis.geo.uj.edu.pl/FORECOM, dostęp: 10 lipca 2020).

${ }^{46}$ „Mapire - The Historical Map Portal” (https://mapire.eu/, dostęp: 6 kwietnia 2020).

47 Dane PZGiK, „Gtówny Urząd Geodezji i Kartografii”” (http://www.gugik.gov. pl/pzgik, dostęp: 12 marca 2020).

${ }^{48}$ „Geoportál ČÚZK" (https://geoportal.cuzk.cz, dostęp: 16 kwietnia 2020).
} 


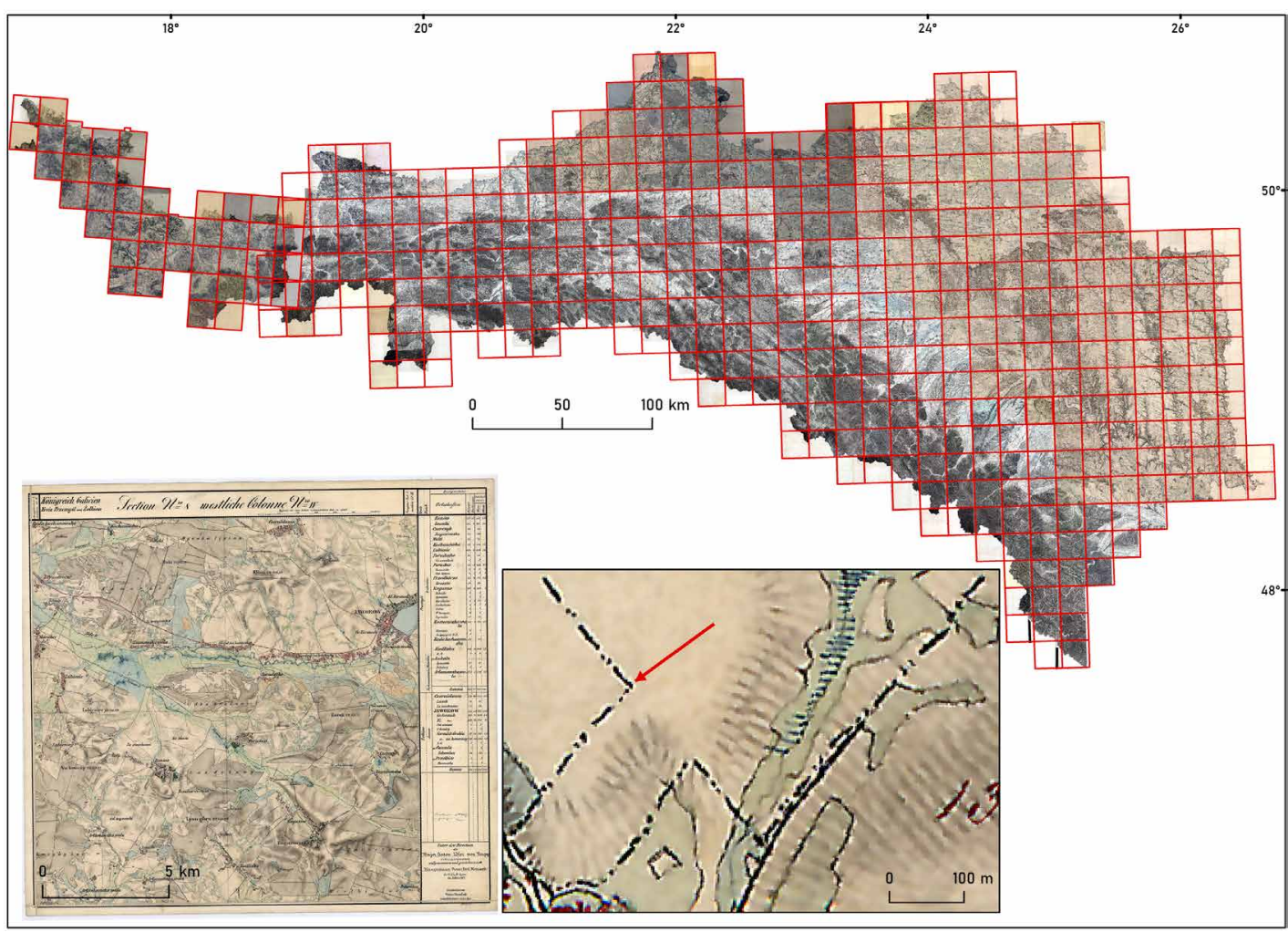

Ryc. 4. Mozaika arkuszy drugiego zdjęcia topograficznego w skali 1:28 000 wraz z przykładowym arkuszem i fragmentem treści z liniowym symbolem granicy gminy katastralnej oznaczonym czerwoną strzatką.

Źródto: oprac. własne

administracyjnych lub ich części (np. las miejski Myślenic), jeśli dysponowano dodatkowymi źródłami, jak plany katastralne. Dla porównania Tadeusz Pilat wykazał 5933 gminy katastralne i 6230 administracyjnych $^{49}$, a Gemeindelexikon z 1900 r. - 5947 gmin katastralnych i 6240 administracyjnych.

W razie trudności z rekonstrukcją granic można wykorzystać punkty reprezentujące powierzchnie gmin i dworów, tak jak zrobili to Dariusz Chojecki i Edward Włodarczyk $^{50}$ wobec obszaru 30 tys. $\mathrm{km}^{2}$ i blisko 4,7 tys. gmin i obszarów dworskich.

Jakość rekonstrukcji granic gmin Galicji i Śląska Austriackiego oceniona została poprzez porównanie powierzchni

\footnotetext{
${ }^{49}$ T. Pilat, Podziat.

${ }^{50}$ D.K. Chojecki, E. Włodarczyk, Topodemograficzny atlas gmin i obszarów dworskich Pomorza Zachodniego w 1871 roku, t. 1, Szczecin 2012.
}

zwektoryzowanych jednostek i analogicznych wartości zawartych w publikacjach statystycznych. W przypadku gmin katastralnych różnice te nie przekraczają na ogół 5 proc., przy czym wartości bezwzględne w dużym stopniu zależą od wielkości gmi$n y^{51}$. W przypadku gmin katastralnych, które tworzą obszar współczesnego Krakowa, największe rozbieżności dotyczą m.in. Dąbia, Płaszowa, Branic i Przylasku Rusieckiego, gdzie znaczny wpływ miały meandry i regulacje Wisły (ryc. 5).

Wiarygodne granice gmin umożliwiają rekonstrukcję innych podziałów terytorialnych na podstawie publikowanych spisów, a przykładem mogą być okręgi sanitarne. Jeśli do okręgu sanitarnego należała

\footnotetext{
51 Przykładowo Półwsie Zwierzynieckie miały w 1900 r. powierzchnię 55 ha, a największa w Galicji gmina katastralna Żabie - 59612 ha.
} 


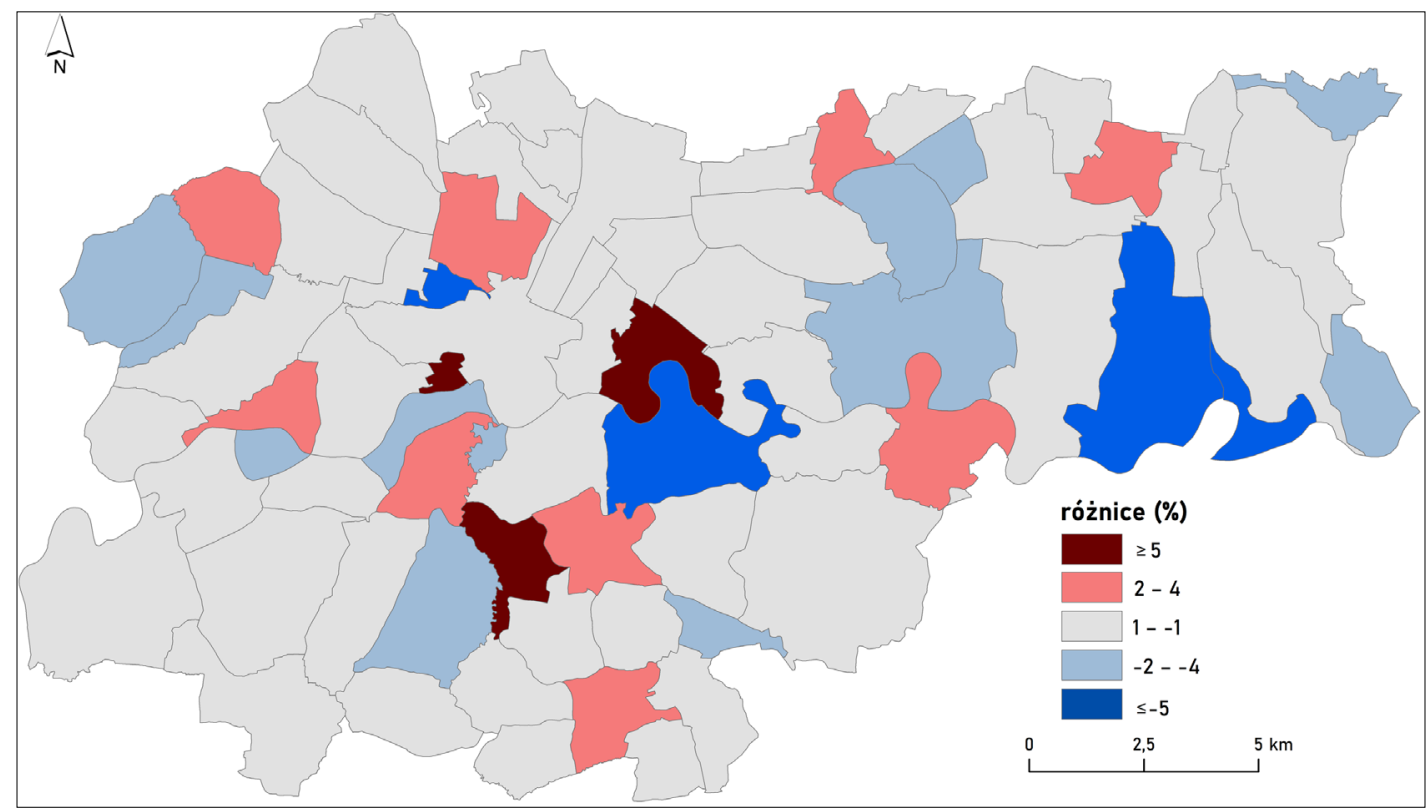

Ryc. 5. Różnice między powierzchniami gmin katastralnych z drugiego zdjęcia topograficznego w skali 1:28 800 oraz „Gemeindelexikonu” Galicji dla 1900 r.52 na obszarze wspótczesnego Krakowa (z wyłączeniem gmin katastralnych, które nie weszły w jego skład w całości).

Źródto: oprac. własne

jedna gmina, nazywano ją gminą sanitarną (niem. Sanitätsgemeinde). Dystrykty sanitarne (niem. Sanitätsdistrikte) to z kolei dwie lub więcej gmin. Blisko 211 gmin zajmujących 71 proc. powierzchni Sląska Cieszyńskiego nie należało do żadnego okręgu sanitarnego (ryc. 6a). Najwięcej z nich znajdowało się w pobliżu Polskiej Ostrawy, gęsto zaludnionego i prężnie rozwijającego się ośrodka przemysłowego związanego z hutnictwem opartym na wydobyciu węgla kamiennego. Warto nadmienić, że na Sląsku Opawskim, zamieszkanym w środkowej i zachodniej części głównie przez ludność niemiecką, było znacznie więcej okręgów sanitarnych niż na Śląsku Cieszyńskim, co prawdopodobnie może być odzwierciedleniem jakości życia na tych obszarach. Innym przykładem podziałów administracyjnych są parafie różnych obrządków. W 1910 r. w obejmującym 35 gmin administracyjnych sądowym

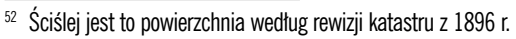

powiecie skoczowskim znajdowało się 10 parafii rzymskokatolickich (ryc. 6b). Parafia w Ustroniu obejmowała wiernych z Wisły i Hermanic, a do parafii w Skoczowie należało aż 9 miejscowości.

Granice katastralne umożliwiają agregację danych do poziomu powiatów politycznych i sądowych, co obarczone jest znacznie mniejszym błędem i niepewnością co do przynależności danej jednostki niż rekonstrukcja granic z map w skalach przeglądowych. Wyjście od poziomu gmin katastralnych jako jednostki podstawowej w znacznej mierze uniezależnia od trudności w integracji danych społeczno-ekonomicznych związanych ze zmianami administracyjnymi na poziomie powiatów ${ }^{53}$. Dobitnie potwierdza to także Tadeusz Pilat, pisząc: „Między innemi cierpi

\footnotetext{
${ }_{53}$ M. Soja, Cykle. W tekście tym do analizy zmian demograficznych w obrębie Karpat Polskich skutecznie przyjęto właśnie poziom miejscowości, a zakres czasowy pracy jest znacznie dłuższy, obejmujący liczne późniejsze zmiany granic, np. likwidację miejscowości, których mieszkańcy zostali wysiedleni w latach czterdziestych XX w.
} 


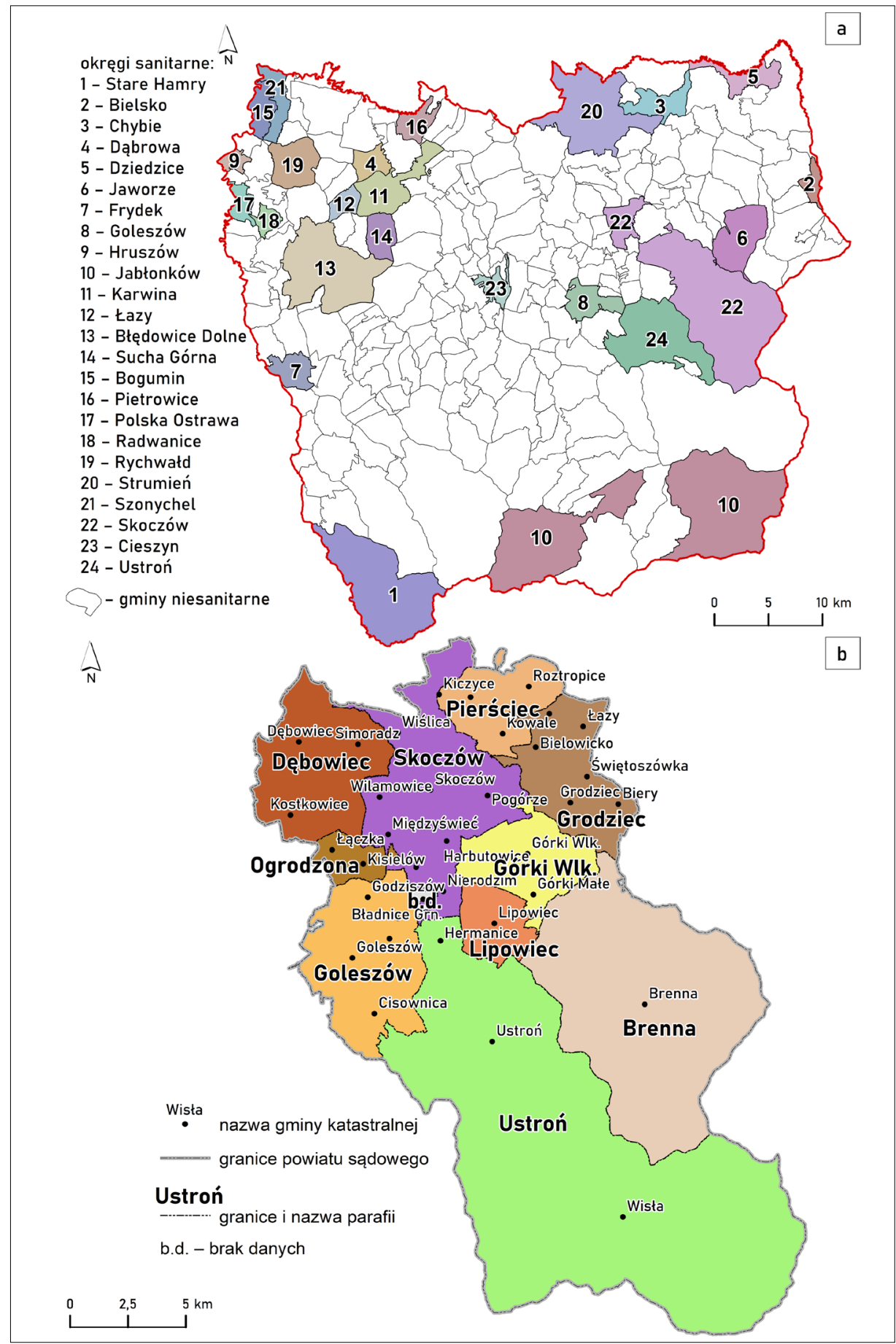

Ryc. 6. Przykłady innych podziałów terytorialnych:

a) podział Śląska Cieszyńskiego na okręgi sanitarne, b) przynależność gmin katastralnych do parafii obrządku rzymskokatolickiego w sądowym powiecie skoczowskim w 1900 r.

Źródło: oprac. własne na podstawie: „Gemeindelexikon”, Bd. 11 


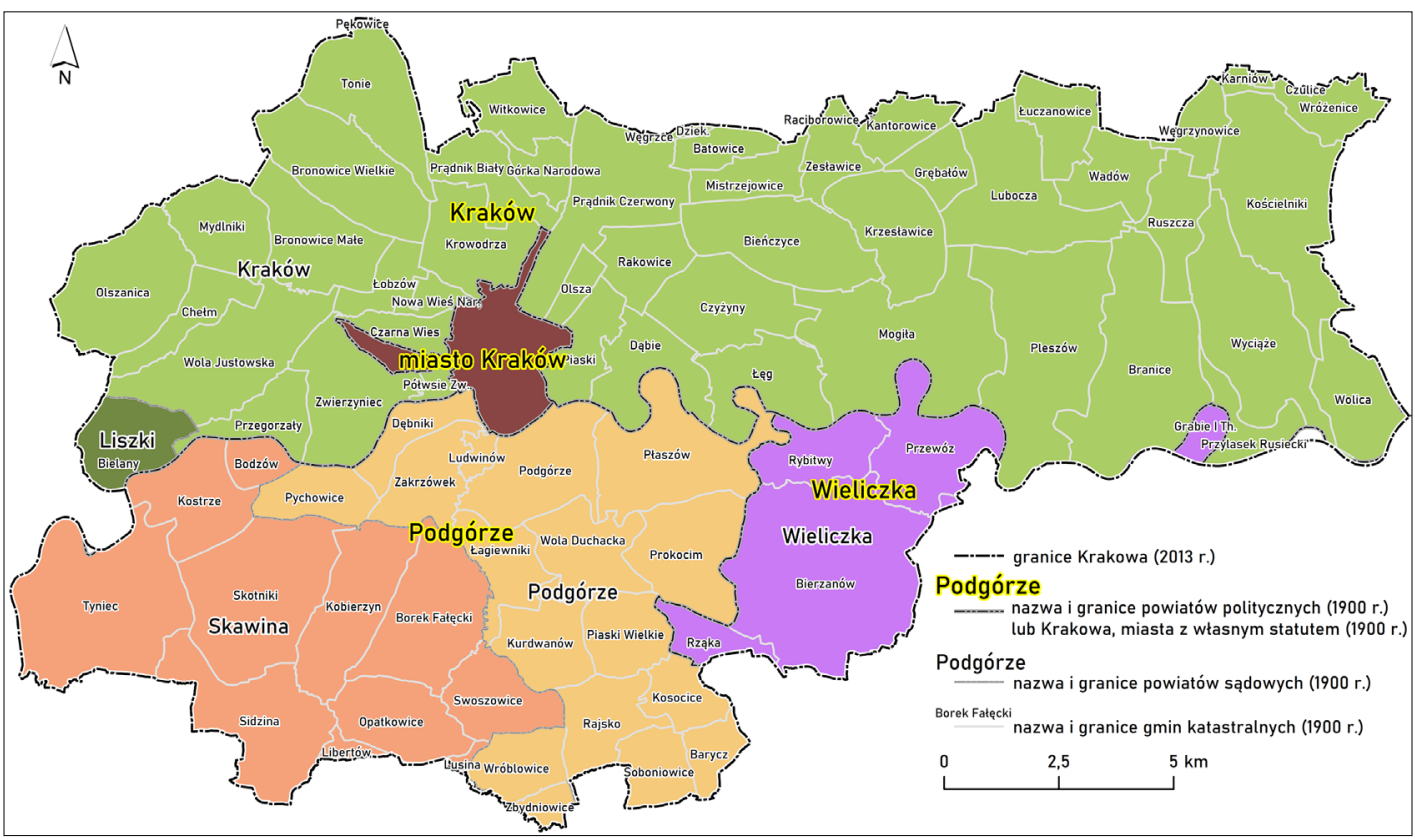

Ryc. 7. Podział wspótczesnego Krakowa na dawne gminy katastralne oraz powiaty polityczne i sądowe według stanu z $1900 r^{54}$ Źródło: oprac. własne (nazwy gmin i powiatów według "Gemeindelexikonu" Galicji dla 1907 r.55)

administracya publiczna a obok niej cierpią prace naukowe przez to, że wskutek zmian w podziale kraju tracą na użyteczności wszelkie zestawienia statystyczne [...]”. W dalszej części swoich obserwacji podaje rozwiązanie tych problemów: „Przystosowanie dat dawniejszych do nowego podziału jest możebnem w ogóle tylko wtedy, jeżeli materyał pierwotny, obejmujący najmniejsze jednostki terytorialne, do których zmiany już się nie odnosiły, pozostał zachowany, a i w takim razie zadanie takie ze względu na trudność uzyskania owego materyału pierwotnego i ze względu na rozległą i mozolną pracę, jakiej wymaga

\footnotetext{
${ }^{54}$ Podobne opracowanie, ale w szerszym horyzoncie czasowym zob. пр.: W. Baka, H. Olszewska-Skubisz, Granice i podziaty administracyjne, w: Atlas miasta Krakowa, red. K. Trafas, M. Hess, Warszawa-Wroctaw 1988; Granice Krakowa, „Poczet Krakowski” (https://www.poczetkrakowski. pl/granice-krakowa/, dostęp: 27 kwietnia 2020).

55 Nazwy te mogą się różnić od najczęściej używanych, np. na drugim arkuszu planu katastralnego z $1848 \mathrm{r}$. widnieje nazwa Dorf Piaski mit der Ortschaft Grzegórski [Grzegórzki] in Galizien Krakauer Kreis, a według prezentującego $\operatorname{stan}$ z 31 grudnia 1900 r. Gemeindelexikonu z 1907 r. gmina katastralna nosita nazwę Piaski i obejmowała dwie gminy administracyjne - Piaski oraz Grzegórzki.
}

przystosowanie dat do nowego podziału, może być spełnionem jedynie przez siły urzędowe" 56 .

Agregacja gmin może być wykonywana wobec dowolnej współczesnej jednostki terytorialnej. Można na przykład rekonstruować $\mathrm{w}$ ten sposób zmiany granic Krakowa aż do współczesności (ryc. 7). Problematyczne mogą się wówczas okazać dawne gminy katastralne, które częściowo weszły w skład współczesnych jednostek terytorialnych (np. niewielkie fragmenty Lusiny i Libertowa stały się częścią Krakowa w 1986 r.).

\subsection{Poziom powiatów}

Powiaty są najczęściej wykorzystywanym poziomem odniesienia przestrzennego w przypadku Galicji i całych Austro-Węgier. Przykładem ich użycia są rzetelne, różnotematyczne, ale tabelaryczne publikacje z serii Informatorów statystycznych do

${ }^{56}$ T. Pilat, Podziat, s. 1. 
dziejów gospodarczych Galicji oraz projekty takie jak HistoGIS ${ }^{57}$ czy Mosaic ${ }^{58}$, udostępniające geometrię granic m.in. odnośnie do niektórych powiatów Galicji i Śląska Austriackiego w różnych przekrojach czasowych lub dla całego obszaru Austro-Węgier według stanu z $1910 \mathrm{r}$.

Nawet po największej reformie administracyjnej w 1866 r. granice galicyjskich powiatów podlegały zmianom. Na przykład powiat myślenicki w latach 1869-1910 zmniejszył swoją powierzchnię o $47,5 \mathrm{~km}^{2}$, przy czym różnica ta stanowiła bilans powierzchni gmin odłączonych i przyłączonych (ryc. 8). W latach 1869-1880 zabrano z niego Bielankę, Chabówkę, Ponice, Rokiciny, Rdzawkę i Sieniawę (w sumie $60 \mathrm{~km}^{2}$ ), a w latach 1890-1900 - Radziszów i Jurczyce (w sumie $17,7 \mathrm{~km}^{2}$ ), przyłączając je odpowiednio do powiatów nowotarskiego (niem. Neumarkt) i podgórskiego. Z kolei do powiatu myślenickiego przyłączono w latach 1869-1880 Budzów $\left(20,4 \mathrm{~km}^{2}\right)$ z powiatu wadowickiego oraz Brzączowice i Zasań (w sumie $9,8 \mathrm{~km}^{2}$ ) z powiatu wielickiego. Aby oszacować, jaki odsetek wartości zmian społeczno-ekonomicznych w danym powiecie spowodowały zmiany administracyjne, należy zrekonstruować granice powiatów na poziomie gmin. $Z$ powiatu myślenickiego w 1869 r. przeniesiono na przykład 582 domy i 3594 mieszkańców do powiatu nowotarskiego.

Agregacja gmin w powiaty daje większą wiarygodność granic powiatów niż pozyskanie ich z map przeglądowych, a sumaryczna powierzchnia może być zweryfikowana na podstawie danych ze źródeł statystycznych i innych projektów. W przypadku omawianego powiatu myślenickiego zwektoryzowany obszar wynosi w 1869 r. 109203 ha wobec 109354 ha podawanych przez Tadeusza

\footnotetext{
${ }^{57}$ „HistoGIS” (https://histogis.acdh.oeaw.ac.at/, dostęp: 27 kwietnia 2020).

58 "Mosaic" (https://censusmosaic.demog.berkeley.edu/, dostęp: 27 kwietnia 2020).
}

Pilata $^{59}$ (różnica 0,13 proc.), a w 1910 r. odpowiednio 104615 wobec 104586 ha $^{60}$ (różnica 0,02 proc.). Dla porównania powierzchnia całego powiatu myślenickiego z mapy w skali 1:750 000 wykonanej w ramach projektu Mosaic wynosi 100204 ha (różnica 4,2 proc.), ale w przypadku poszczególnych powiatów sądowych różnice są jeszcze większe i wynoszą: 2,7 proc. w jordanowskim, 7,9 proc. w makowskim oraz 9,5 proc. w myślenickim.

Szczegółowe i wiarygodne granice powiatów politycznych i sądowych umożliwiają połączenie z tabelarycznymi publikacjami Centralnej Komisji Statystycznej w Wiedniu, jak serie Tafeln zur Statistik der oesterreichischen Monarchie ${ }^{61}$, Statistisches Jahrbuch $^{62}$ czy Österreichische Statistik ${ }^{63}$, oraz wizualizację różnych tematów społeczno-gospodarczych jako mapy.

\section{Podsumowanie}

Właściwy dobór jednostek odniesienia przestrzennego jest problemem badawczym, który wymaga rozważenia wielu kryteriów. Powinny one uwzględniać przede wszystkim dostępność, spójność i wiarygodność materiałów źródłowych oraz nakład czasu i pracy potrzebny do ich przygotowania ${ }^{64}$. Dobór jednostek historycznych może nawiązywać także do współczesnych referencyjnych baz danych. Dane źródłowe $\mathrm{z}$ drugiej połowy XIX

\footnotetext{
59 Wartość w hektarach przeliczona z 19,0025 mil kwadratowych austriackich podanych w tablicy III publikacji: T. Pilat, Statystyka gminna, „Wiadomości Statystyczne o Stosunkach Krajowych", 4, 1878. Autor podaje tam m.in. zestawienia ze spisu ludności z $1869 \mathrm{r}$.

60 Wartość w hektarach przeliczona z 1045,86 km² podanych w tablicy II publikacji: T. Pilat, Najważniejsze wyniki spisu ludności i spisu zwierząt domowych według stanu zd. 31 grudnia 1910 r., ,Wiadomości Statystyczne o Stosunkach Krajowych", 25 (1), 1911.

${ }^{61}$ Tafeln zur Statistik der oesterreichischen Monarchie, Wien 1828-1865.

62 Statistisches Jahrbuch, Wien 1863-1881.

63 Österreichische Statistik, Wien 1880-1910.

${ }^{64}$ Oprócz autorów niniejszej pracy projekt opracowania bazy danych dotyczącej Galicji i Śląska Austriackiego zasilają lub zasilali swoją pracą i wiedzą (w porządku alfabetycznym): mgr inż. Monika Dobosz, mgr Aleksandra Dul, dr inż. Natalia Kolecka, dr Wojciech Maciejowski, mgr Anna Miklar, dr Adam Szczupak, mgr Marcin Szwagrzyk, dr hab. Konrad Wnęk, mgr Bartosz Załuski i dr Lidia Zyblikiewicz. Składamy im serdecznie podziękowania za wspótpracę.
} 

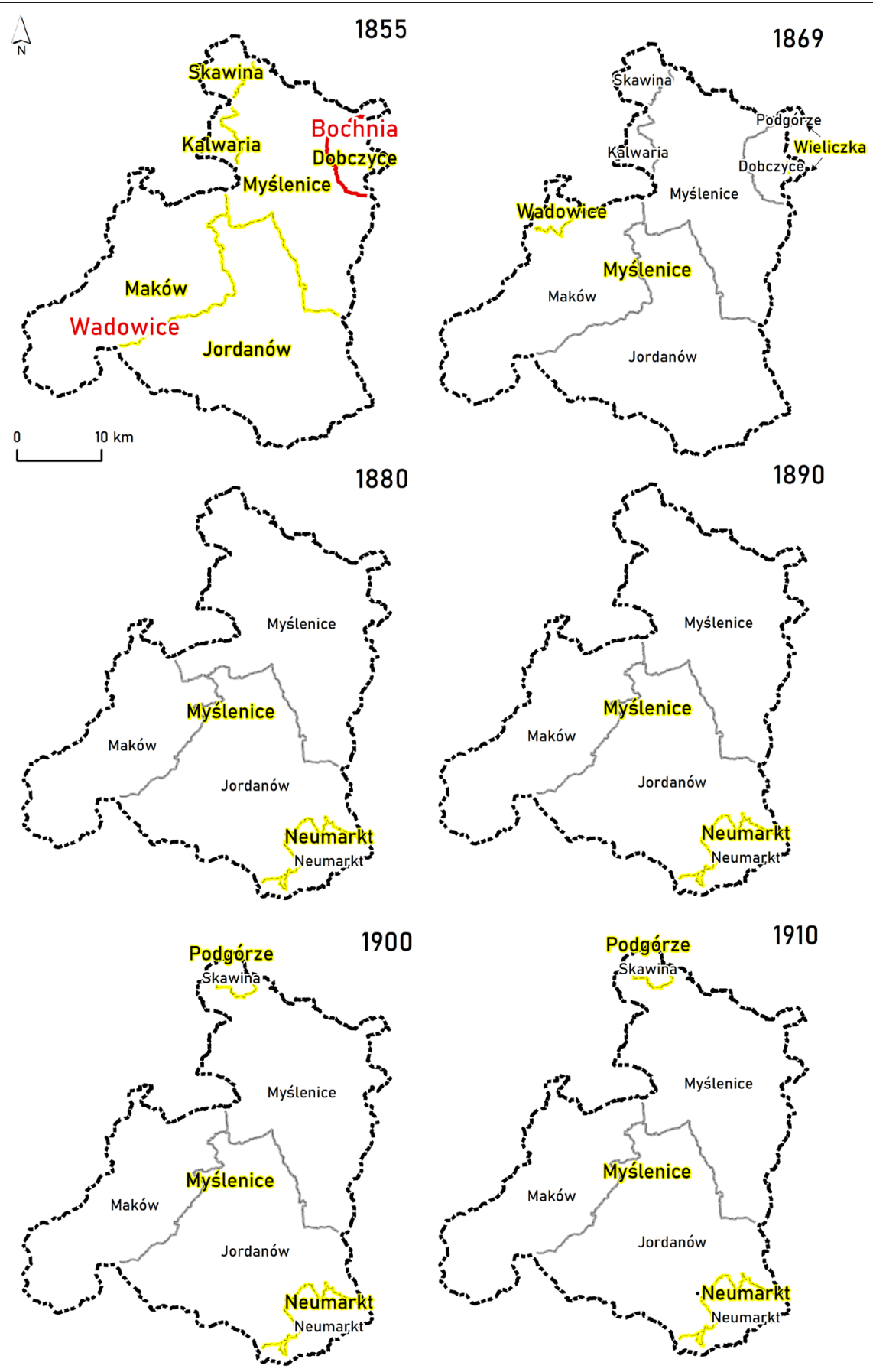

-... sumaryczny, maksymalny obszar miejscowości należących do powiatu myślenickiego w latach 1855-1910

— obwód, cyrkuł (niem. Kreis) —— powiat/powiat polityczny (niem. Bezirk) —— powiat sądowy (niem. Gerichtsbezirk)

Ryc. 8. Zmiany granic powiatu myślenickiego w latach 1855-1910.

Żródto: oprac. własne 
i początku XX w., nawet odnoszące się do bardzo dużych obszarów, mogą być organizowane masowo od poziomu dzisiejszych obrębów ewidencyjnych wsi i miast jako łatwo edytowalne, otwarte pliki zawierające geometrię i atrybuty opisowe obsługiwane przez systemy informacji geograficznej. Taki dobór poziomu jednostek odniesienia

\section{Bibliografia}

Affek A., Dynamika krajobrazu. Uwarunkowania i prawidtowości na przyktadzie dorzecza Wiaru w Karpatach (XVIII-XXI wiek), Warszawa 2016 (Prace Geograficzne IGiPZ PAN, 251).

Allgemeines Verzeichnis der Ortsgemeinden und Ortschaften Österreichs nach den Ergebnissen der Volkszählung vom 31. Dezember 1910, Wien 1915.

Alphabetifch geordnetes Orts = Verzeichnitz der Kronländer Mähren und Schlefien nach der k. k. politifchen Adminiftrations und Gerichtseintheilung, OlmüzNeutitfchein 1850.

Atlas miasta Krakowa, red. K. Trafas, M. Hess, Warszawa-Wrocław 1988.

Baka W., Olszewska-Skubisz H., Granice i podziaty administracyjne, w: Atlas miasta Krakowa, red. K. Trafas, M. Hess, Warszawa-Wrocław 1988.

„Bank Danych Lokalnych” (https://bdl.stat.gov.pl/ BDL/start, dostęp: 6 kwietnia 2020).

Burzyński A., Górnictwo, hutnictwo i przemyst rafineryjny (struktura zatrudnienia na tle wartości i wielkości produkcji), w: Informator statystyczny do dziejów przemystu $w$ Galicji, red. H. Madurowicz-Urbańska, Kraków 1982.

Burzyński A., $Z$ rozważań nad ocena austriackich powszechnych spisów ludności z lat 1869-1910, „Przeszłość Demograficzna Polski”, 15, 1984.

„Český statistický úřad” (https://www.czso.cz/, dostęp: 6 kwietnia 2020).

Chlebowczyk J., Gospodarka Komory Cieszyńskiej na przetomie XVII-XVIII oraz w pierwszej potowie XVIII w., Wrocław-Warszawa-Kraków 1966.

Chłapowski K., Granice i podziaty administracyjne Królestwa Polskiego i Rzeczypospolitej Obojga Narodów wXV-XVIII wieku, „Studia Geohistorica”, 7, 2019.

Chojecki D.K., Włodarczyk E., Topodemograficzny atlas gmin i obszarów dworskich Pomorza Zachodniego w 1871 roku, t. 1, Szczecin 2012.

Chromik G., Geschichte des deutsch-slawischen Sprachkontaktes im Teschener Schlesien, Regensburg 2018.

Dane PZGiK, „Główny Urząd Geodezji i Kartografii” (http://www.gugik.gov.pl/pzgik, dostęp: 12 marca 2020). przestrzennego pozwala w znacznym stopniu uniezależnić analizy od późniejszych zmian administracyjnych, wyznaczając też wiarygodną podstawę do integracji obrazu wektorowego z różnymi danymi społeczno-gospodarczymi na dowolnym szczeblu administracyjnym.

Domański C., Rola polskich statystyków w Międzynarodowym Instytucie Statystycznym, „Przegląd Statystyczny”, 62 (4), 2015.

Dziadzio A., Mataniak M., Namiestnictwo galicyjskie (1854-1914). Organizacja i zadania, „Krakowskie Studia z Historii Państwa i Prawa”, 11 (1), 2018.

EU-DEM v.1.1, „Copernicus” (https://land.copernicus.eu/imagery-in-situ/eu-dem/eu-dem-v1.1, dostęp: 27 kwietnia 2020).

Faluszczak F.P., Kartografia Galicji Wschodniej w latach 1772-1914, Rzeszów 2011.

„FORECOM” (http://www.gis.geo.uj.edu.pl/FORECOM, dostęp 10 lipca 2020).

„Der Franziszeische Kataster” (http://www.franziszeischerkataster.at, dostęp: 27 kwietnia 2020).

Galicja na józefińskiej mapie topograficznej. 1779-1783, t. 1, red. W. Bukowski, B. Dybaś, Z. Noga, Kraków 2012.

Gawrecki D., Granice i zmiany przynależności Śląska Cieszyńskiego do 1918 roku, w: Ślask Cieszyński. Granice - przynależność - tożsamość, red. J. Spyra, Cieszyn 2008.

Gemeindelexikon der im Reichsrate vertretenen Königreiche und Länder, Bd. 5: Kärnten, Wien 1905.

Gemeindelexikon der im Reichsrate vertretenen Königreiche und Länder, Bd. 11: Schlesien, Wien 1906.

Gemeindelexikon der im Reichsrate vertretenen Königreiche und Länder, Bd. 12: Galizien, Wien 1907.

Gemeindelexikon der im Reichsrate vertretenen Königreiche und Länder, Bd. 13: Bukowina, Wien 1907.

„Geoportál ČÚZK” (https://geoportal.cuzk.cz, dostęp: 16 kwietnia 2020).

Granice Krakowa, „Poczet Krakowski” (https://www. poczetkrakowski.pl/granice-krakowa/, dostęp: 27 kwietnia 2020).

„HistoGIS” (https://histogis.acdh.oeaw.ac.at/, dostęp 27 kwietnia 2020).

Informator statystyczny do dziejów przemystu w Galicji, red. H. Madurowicz-Urbańska, Kraków 1982.

Instruktion zur Ausführung der Vermessungen mit Anwendung des Mesztiches behufs Herstellung neuer Pläne für die Zwecke des Grundsteuerkatasters, Vienna 1907. 
Kasparek F., Uwagi krytyczne o galicyjskiej organizacyi gminnej i wnioski reformy, Kraków 1880.

Kieniewicz S., Sprawa wtościańska w Galicji w 1848, „Przegląd Historyczny”, 38, 1948.

Knowles A.K., Introducing historical GIS, w: Past time, past place. GIS for history, ed. A.K. Knowles, Redlands 2002.

Kocurek D., Korzeniowska W., Ślask Cieszyński w latach 1741-1918 w aspekcie czynników integrujacych $i$ dezintegrujacych region. Studium monograficzne, Kraków 2013.

Konias A., Kartografia topograficzna Ślaska Cieszyńskiego $i$ zaboru austriackiego od II potowy XVIII wieku do początku XX wieku, Katowice 2000.

Kraak M.-J., Ormeling F., Kartografia. Wizualizacja danych przestrzennych, Warszawa 1998.

Kummerer Ritter von Kummersberg C., Administrativ-Karte von den Königreichen Galizien und Lodomerien mit dem Grossherzogthume Krakau und den Herzogthümern Auschwitz, Zator und Bukowina in 60 Blättern, Wien 1855.

„Mapire - The Historical Map Portal” (https://mapire. eu/, dostęp: 6 kwietnia 2020).

„Mosaic” (https://censusmosaic.demog.berkeley.edu/, dostęp: 27 kwietnia 2020).

Nowak D., Austriackie katastry gruntowe $w$ zasobach Centralnego Historycznego Archiwum Państwowego Ukrainy we Lwowie, „Krakowskie Pismo Kresowe”, 11, 2019.

Nowak K., Przemiany prawno-administracyjne, spoteczno-zawodowe i narodowościowe, w: Ślask Cieszyński od Wiosny Ludów do I wojny światowej (1848-1918), red. I. Panic, Cieszyn 2013.

Ostafin K., Kaim D., Siwek T., Miklar A., Historical dataset of administrative units with social-economic attributes for Austrian Silesia 1837-1910, „Scientific Data”, 7 (208), 2020.

Österreichische Statistik, Wien 1880-1910.

Past time, past place. GIS for history, ed. A.K. Knowles, Redlands 2002.

Pilat T., Najważniejsze wyniki spisu ludności i spisu zwierzat domowych wedtug stanu $z d .31$ grudnia 1910 r., „Wiadomości Statystyczne o Stosunkach Krajowych”, 25 (1), 1911.

Pilat T., Podziat terytoryalny Galicyi wedtug stanu zd. 1. stycznia 1883 r. tudzież obszar, ludność i gestość zaludnienia powiatów, „Wiadomości Statystyczne o Stosunkach Krajowych”, 8 (1), 1883.

Pilat T., Statystyka gminna, „Wiadomości Statystyczne o Stosunkach Krajowych", 4, 1878.

Pilat T., Wtasność tabularna w Galicyi, „Wiadomości Statystyczne o Stosunkach Krajowych”, 12, 1891.

Projekt podziatu administracyjnego Królestwa Galicyi, Lodomeryi $i$ W. Ks. Krakowskiego na 74 powiaty, Lwów 1866.
Rumpler H., Scharr K., Ungureanu C., Der Franziszeische Kataster im Kronland Bukowina Czernowitzer Kreis (1817-1865). Statistik und Katastralmappen, Wien-Köln-Weimar 2015.

Rutkowski H., A few comments on the historical borders in Poland, „Studia Geohistorica”, 6, 2018.

Rzepkowski A., Spisy ludności na ziemiach polskich w latach 1789-1939, „Przegląd Nauk Historycznych", 2 (8), 2005.

Sched J., General-Karte des Oesterreichischen Kaiserstaates mit einem grossen Theile der angränzenden Länder, skala: 1:576 000, 1856.

Sobala M., Rahmonov O., Myga-Piątek U., Historical and contemporary forest ecosystem changes in the Beskid Mountains (southern Poland) between 1848 and 2014, ,iForest - Biogeosciences and Forestry”, 10, 2017.

Soja M., Cykle rozwoju ludności Karpat Polskich w XIX i XX wieku, Kraków 2008.

Spezial Orts-Repertorium von Schlesien Neubearbeitung auf grund der ergebnisse der Volkszählung vom 31. Dezember 1890, Wien 1894.

Spezialortsrepertorium der Österreichischen Länder. Bearbeitet auf grund der ergebnisse der Volkszählung vom 31. Dezember 1910, Herausgegeben von der K.K. Statistischen Zentralkommission XI. Schlesien, Wien 1917.

Statistische Übersichten über die Bevölkerung und den Viehstand von Österreich nach der zählung vom 31. October 1857, Wien 1859.

Statistisches Jahrbuch, Wien 1863-1881.

Stoksik J., Galicyjski kataster gruntowy - jego gromadzenie i opracowywanie w Archiwum Państwowym w Krakowie, „Krakowski Rocznik Archiwalny”, 1, 1995.

Stoksikówna J., Galicyjski kataster gruntowy, jego geneza, dzieje i spuścizna aktowa, „Archeion”, 63, 1975.

Szady B., Czasowo-przestrzenne bazy danych jako narzędzie w geografii historycznej, „Acta Universitatis Lodziensis. Folia Geographica Socio-Oeconomica”, 14, 2013.

Szady B., Geografia historyczna w Polsce - rozwój i perspektywy, „Studia Geohistorica”, 1, 2013.

Ślask Cieszyński. Granice - przynależność - tożsamość, red. J. Spyra, Cieszyn 2008.

Ślask Cieszyński od Wiosny Ludów do I wojny światowej (1848-1918), red. I. Panic, Cieszyn 2013.

Ślusarek K., W przededniu autonomii. Wtasność ziemska i ziemiaństwo zachodniej Galicji w potowie XIX wieku, Warszawa 2013.

Tafeln zur Statistik der oesterreichischen Monarchie, Wien 1828-1881.

Teibenbacher P., Kramer D., Göderle W., An inventory of Austrian census materials, 1857-1910. Final report, Rostock 2012 (Mosaic Working Paper, WP2012-007). 
Ustawa z dnia 26 lipca 1919 r. o potaczeniu obszarów dworskich z gminami, obowiąująca na terytorium b. Galicji, Dz.U. 1919, nr 67, poz. 404.

Wnęk K., Wtasność nieruchomości w Krakowie w potowie XIX w., Kraków 2011.

Wolski J., Austriacki kataster podatku gruntowego na ziemiach polskich oraz jego wykorzystanie w pracach urzadzeniowych i badaniach naukowych, "Polski Przegląd Kartograficzny”, 32 (3), 2000.

Wolski J., Przeksztatcenia krajobrazu wiejskiego Bieszczadów Wysokich w ciagu ostatnich 150 lat, Warszawa 2007 (Prace Geograficzne IGiPZ PAN, 214).
World Imagery, „Arc GIS” (https://www.arcgis.com/ home/item.html?id=10df2279f9684e4a9f6a7f08febac2a9, dostęp: 6 kwietnia 2020).

Zyblikiewicz L.A., Ludność Krakowa $w$ drugiej potowie XIX wieku. Struktura demograficzna, zawodowa i spoteczna, Kraków 2014.

Żyszkowska W., Analizy przestrzenne w systemach informacji geograficznej, „Polski Przegląd Kartograficzny”, 35 (2), 2003.

\section{Problem of selection of territorial units in the integration of data from the second half of the $19^{\text {th }}$ century and the beginning of the $20^{\text {th }}$ century for Galicia and Austrian Silesia}

\section{Summary}

This article aims to present problems in the selection of historical territorial units to be combined with published socio-economic census data. The proper selection of spatial reference units is a research problem that requires consideration of many criteria. These criteria should take into account, in particular, the availability, coherence and reliability of the source material, as well as the time and effort required to process it. The selection of historical territorial units may also refer to contemporary reference databases containing registers of boundaries or geographical names.

When analysing a large area (over 80.000 $\mathrm{km}^{2}$ ) that is divided by modern national borders (Ukraine, Poland, Czech Republic), one faces a dilemma - what is the most effective spatial reference level? It is difficult to adopt a level of detail greater than that of the cadastral commune in this case due to its demands in terms of labour and time. It is generally adopted for areas of tens or hundreds of square kilometres, and the spatial reference level is cadastral parcels, settlements, or land use complexes in communes.

The cadastral commune level also requires a great deal of work. This effort is worthwhile because the historical maps from the mid-nineteenth century in scales close to $1: 25,000$ make it possible to reconstruct the areas of communes with an accuracy of a few percent. As a result of manual vectorisation, nearly 6,700 commune boundaries were obtained. Aggregation of communes into districts lends more credibility to the district boundaries than obtaining them from maps at smaller scales, as is generally done in many projects. Selection of this level of spatial reference unit makes spatial analyses largely independent of subsequent administrative changes. Other administrative divisions such as the parishes of various rites or sanitary districts can also be reconstructed on the basis of commune boundaries.

The district level is often used due to the easy availability of extensive socio-economic lists published in series such as Tafeln zur Statistik or Österreichische Statistik. However, districts may not be sufficient to understand changes in socioeconomic processes due to frequent administrative changes and thus the incomparability of spatial reference units.

dr Krzysztof Ostafin - geograf, adiunkt w Instytucie Geografii i Gospodarki Przestrzennej Uniwersytetu JagielIońskiego w Krakowie. Interesuje się zmianami w krajobrazie i pracuje z różnymi źródłami danych geograficznych jak mapy i plany historyczne oraz zdjęcia satelitarne. Obszarami jego aktywności badawczej są głównie Karpaty i Spitsbergen. W Karpatach przebywa zazwyczaj na co dzień, a na Spitsbergenie uczestniczył w dwóch wyprawach badawczych w 2005 i 2016 r.

(krzysztof.ostafin@uj.edu.pl) 
dr Mateusz Troll - geograf, kierownik Zbiorów Kartograficznych oraz starszy wykładowca w Zakładzie Systemów Informacji Geograficznej, Kartografii i Teledetekcji Instytutu Geografii i Gospodarki Przestrzennej Uniwersytetu Jagiellońskiego w Krakowie (mateusz.troll@uj.edu.pl)

dr Dominik Kaim - geograf, adiunkt w Instytucie Geografii i Gospodarki Przestrzennej Uniwersytetu Jagiellońskiego. Zajmuje się tematyką zmian użytkowania ziemi w obszarach górskich na podstawie różnorodnych materiałów, w tym archiwalnych map oraz archiwalnych fotografii naziemnych (dominik.kaim@uj.edu.pl)

dr Jakub Taczanowski - geograf społeczno-ekonomiczny, adiunkt w Instytucie Geografii i Gospodarki Przestrzennej Uniwersytetu Jagiellońskiego w Krakowie. Interesuje się geografią transportu, zwłaszcza szynowego i miejskiego, a także geografią miast i geografią historyczną. Obszarami jego zainteresowań badawczych są w szczególności Europa Środkowa oraz Włochy

(jakub.taczanowski@uj.edu.pl)

Krzysztof Ostafin, PhD - geographer, assistant professor at the Institute of Geography and Spatial Management of the Jagiellonian University in Kraków. He specializes in landscape changes of mountainous areas and works with different sources of geographical data, for example, old maps, plans and satellite images. He lives in the Carpathians and took part in the expeditions to Sørkapp Land in 2005 and 2016 (krzysztof.ostafin@uj.edu.pl)

Mateusz Troll, PhD - geographer, head of the Map Collection and senior lecturer at the Department of GIS, Cartography and Remote Sensing of the Institute of Geography and Spatial Management, Jagiellonian University in Kraków

(mateusz.troll@uj.edu.pl)

Dominik Kaim, PhD - geographer, assistant professor at the Institute of Geography and Spatial Management, Jagiellonian University in Kraków; his research is focused on the land use changes in mountain areas, based on various data sources, incl. archival map and terrestrial photography

(dominik.kaim@uj.edu.pl)

Jakub Taczanowski, PhD - socio-economic geographer, assistant professor at the Institute of Geography and Spatial Management of the Jagiellonian University in Kraków. He is interested in transport geography, especially rail and urban transport as well as in urban and historical geography. His research areas are in particular Central Europe and Italy

(jakub.taczanowski@uj.edu.pl) 